\title{
Science in times of crisis
}

\author{
Budget cuts and administrative changes that have eliminated the Ministry of Science in Spain illustrate the need to \\ safeguard science funding and policies in European countries immersed in the economic crisis.
}

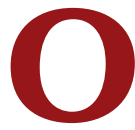
n 21 December, Spain's new prime minister announced that the science ministry would be among three ministries to disappear in the ongoing effort to rein in spending. Research and development (R\&D) policies will now fall under the Ministry of Economy and Competition. Moreover, the R\&D budget will be cut by $€ 600$ million (about $\$ 760$ million, a $7 \%$ reduction of the current budget) (see page 184). Although the long-term impact of these governance changes and austerity measures is hard to predict, they follow a series of setbacks for Spanish science and represent a worrisome indicator of a possible widespread scientific downturn in other European countries.

Science policy and funding in Spain seem to do better with oversight from a separate science ministry. In its latest incarnation, from 2008 to 2011, the Ministry of Science ushered in muchneeded legal reforms to improve the job status of students and postdoctoral researchers, fostered technology transfer, and created independent funding bodies, as well as a State Research Agency. It also implemented excellence programs to inject funds into flagship institutes and continued initiatives launched under the auspices of a previous administration's Ministry of Science, such as the Ramón y Cajal program to recruit young investigators. Even though budget cuts of $8 \%$ in 2010 and 15\% in 2009 may have threatened some of these initiatives, the existence of a science ministry represented a forum to which scientists could direct their concerns and where stakeholders could participate in policy making.

The overall goal of scientific policies in Spain has been to increase the international presence of Spanish science by raising investment to levels similar to those in leading countries. Before it was blunted by the economic downturn, the steady climb in science investment checked in at $1.37 \%$ of Spain's gross domestic product, still below the EU average of $2 \%$ and far from the $2.7 \%$ in the US and the $3.3 \%$ in Japan. Arguably, the most visible development in the last decade was in expanded infrastructure, with ambitious cutting-edge institutes focused on several disciplines, such as cancer research, cardiovascular diseases and regenerative medicine. But, although building research facilities can be a rewarding political stance, this attempt at scientific modernization may not have been undertaken with sufficient long-term vision, or strong enough oversight, to ensure sustainable growth. The potential problems of the strategy adopted by Spain became evident last year when the Principe Felipe Research Center, a stem cell facility, had to fire more than 100 employees and close several lines of research in the midst of allegations of financial mismanagement. This unprecedented move could extend to other institutes in Spain if funding continues to falter, and reflects the need for consistent policies that guarantee long-term support for scientific projects.

Europe's economic turmoil may similarly affect science in other countries in which it traditionally depends heavily on national and European funds. In Greece, in the midst of budget cuts, a legal reform of research administration is under way to preserve the fading competitiveness of public research institutes. And in Italy, where science funding is also dwindling, private investors had to be called in to take over the prestigious San Raffaele Institute. A shift toward private investment has also been proposed by the UK's science minister, who hopes to lure foreign institutions and corporations into partnering with British centers.

Safeguarding science in times of crisis might require making it a more competitive enterprise in European countries. This likely involves broader changes than just promoting research or diversifying funding sources. In Spain, scientific publications have thrived under an environment of increased investment, but the number of patents remains stagnant. Spain's biotechnology industry continues to grow slowly, but it still struggles to attract investors and reach global competitive standards. The already limited pharmaceutical industry is being battered by budget cuts trying to curb health costs and by woefully late payments by the government. The biotechnology and pharmaceutical industries are essential components needed to transform scientific discoveries into products, and thereby revenue, and without their strong presence it will be difficult for research to feed back into economic growth.

Effective scientific policies should integrate the promotion of basic research with incentives for applied industry so as to potentiate science's impact on national economies. In the current stunted economy, science may be sacrificed in favor of more immediate revenue-generating enterprises. In struggling countries such as Spain, political reforms should be undertaken with caution and a clear vision to allow sustainable scientific growth and to guarantee that, with or without its own ministry, science will not be forgotten in times of crisis. 